\title{
PARTICIPATORY LANDSCAPE PLANNING: THE CASE OF THE "WESTVAARDERSPLASSEN" IN THE NETHERLANDS
}

\author{
Anouk GEVAERT, Stefan Jonathan KUPERS, Wim HEIJMAN*
}

\author{
Address: \\ Wageningen University, P.O. Box 8130, 6700 EW Wageningen, the Netherlands \\ *Corresponding Author, e-mail: wim.heijman@wur.nl
}

\begin{abstract}
Although it has been recognised that a stakeholder approach is important in effective landscape planning, a lack of objective methods which include stakeholder opinions in planning projects exists. In this paper we describe a new experimental method for creating landscape planning maps based on stakeholder opinions. During interviews, stakeholders are asked to rate the suitability of individual landscape elements and to visualise their ideal landscape plan. The results of the interview are then used to create a new landscape plan for the area. This method is illustrated by means of a case study in the Netherlands in which four stakeholders were included: the municipality, an agricultural organisation, the water board and a nature conservation organisation. In addition, a sensitivity analysis was performed in order to determine the robustness of the proposed method. Changing weights given to the individual stakeholders did not have a significant influence on the resulting landscape plan, indicating that this is a promising method for participatory landscape planning.
\end{abstract}

Keywords: landscape planning, participatory planning, stakeholder approach, bottom-up approach JEL: R52, R58

\section{INTRODUCTION}

Landscapes are continuously changing over time (Opdam et al., 2006), being altered by natural causes and, especially, by human activities. Human population growth and changes in lifestyle are the main drivers of landscape alterations (Heide et al., 2013). Since the second half of the 20th century, liberalised capitalism has started to increasingly affect communities and landscapes throughout the world, contributing to landscape degradation. In rural areas, agricultural intensification has increasingly created conditions which are harmful to the environment (Roe, 2007). Careful landscape planning is therefore needed for sustainable landscape development, taking into account the complex interactions between ecological processes, biophysical circumstances, economic activities and the institutional situation (Heide et al., 2013).

One requirement for sustainable development is that decisions are made by the communities closest to them, this being called the subsidiarity principle (Selman, 1996). This provides the basis for community participation, where the community (consisting of several social networks often in one location or landscape) is involved in the planning, implementation and maintenance of changes in their environment (Roe 2007). Several European studies have shown that inclusion of stakeholder opinions is an essential part of successfully planning new landscapes (Luz, 2000; Opdam et al., 2006; Tress and Tress, 2003).

From an economic viewpoint, landscapes are composed of characteristics (Lancaster, 1966; Price,
2008). The preferred landscape for the average consumer is the optimum combination of possible landscape characteristics. Maximum utility or welfare from the landscape is gained when the actual landscape planning matches the optimum landscape preferred by the consumers (Heijman et al., 2009). Therefore, if the "landscape manager" aims for maximum utility for the users of the landscape, participatory planning in one way or the other is necessary.

The importance of real involvement of the community in participatory planning has become very clear in the Netherlands. In accordance with the European Landscape Convention, the municipalities have been given increasing responsibility for landscape management (Baas et al., 2011). A municipality could formulate a Landscape Development Plan (LPD), which was subsidised until 2009 by the government. These LPDs were intended to support local and regional initiatives for the preservation of Dutch landscapes. However, even though an LPD was formulated by the general public and professionals, the influence of nonprofessionals tended to be limited. However, since 2009, a new policy instrument called a Village Surrounding Plan (VSP) has been developed, which works at a more local level. One example of a VSP is found on the island Texel, where local farmers and entrepreneurs of the village Den Hoorn created a plan to develop potential for sustainable tourism. Practical changes in the landscape transform the area from agricultural to recreational, and the community is responsible for it. This is regarded as 'local ownership in its purest form' (Baas et al., 2011). Other bottom-up initiatives in the Netherlands showed 
the same positive results such as In Natura, an umbrella organisation of 30 local initiatives of farmers and residents to protect nature and cultural history and revive socio-economic activities (Selman, 2004).

However, although the necessity of involving local representatives is now widely appreciated, there is still no effective universal tool for such bottom-up landscape planning and design which can combine individual ideas practically and effectively. The existing methods are too expensive and/or take too much time to perform, for instance a choice experiment survey (Garrod and Willis, 1999; Louviere et al., 2000). There is a clear need to find a practical way of allowing civilians or stakeholder representatives to participate in landscape planning over a shorter period of time. This article demonstrates a new method to process stakeholders' opinions and convert these opinions into one final landscape plan by means of a case study.

\section{MATERIAL AND METHODS}

The landscape planning process applied to the study area in the Netherlands consisted of two phases. In the first phase, stakeholder interviews were held to involve important parties of the region in the project and the planning process. The aim of the interviews was to learn about each stakeholder's opinions on individual landscape elements as well as their views on what the new landscape plan should look like. In the second phase, these visualisations were combined into one final landscape plan of the study area. In addition, a sensitivity analysis of the method was performed.

\section{Study area}

The new landscape planning method was applied to a study area of 100 ha area located in the municipality "Hollands Kroon" along the IJsselmeer, a large, shallow, artificial lake (Figure 1). The study area is mainly agricultural, but also includes a village, a small forest and a work and refuge harbour on the lake. A dike forms a straight border between the farmland and the lake, except for one former breach close to the forest, commonly known as the hole in the dike'. The entire area lies 2.5 to 5.0 meters below sea level (Bodemrichtlijn, 2012). It is expected that in the future, water safety and socioeconomic changes will become important issues in the study area.

The fact that the land is below sea level makes the area vulnerable to the rise in sea level, predicted to amount to 0.2 to 0.6 meters this century (IPCC, 2007), which is an acceleration (Church and White, 2006) compared to the rate of 0.5 to $2.0 \mathrm{~mm} /$ year during the 20th century (Warrick and Oerlemans, 1990). Higher water levels in the North Sea not only threaten water safety behind the dikes, but are also expected to increase the rate of salt water seepage (Sherif and Singh, 1999), especially in deep polders (Oude Essink et al., 2010). In addition, though the area does not border the sea, rising water levels in the IJsselmeer will increase the risk of flooding.

Apart from these water management concerns, the area also faces socio-economic issues as people are leaving the area (De Zeeuw, pers. comm. 2012). Depopulation of rural areas is mainly due to a lack of job opportunities or lower incomes compared to urban areas (Grgić et al., 2010) and a lack of higher education institutions (Rees et al., 1998; Alston, 2004). Such diminished economic viability and the uncertain situation as regards employment are often regarded as problems in rural areas (Roe, 2007). As fewer people remain, facilities such as schools and public transport disappear, which can lead to further decreases in quality of life in rural villages (Ouředníček et al., 2011). For example, schools not only have an educational task, but also serve as informal meeting places (Haartsen and Van Wissen, 2012).

A new landscape plan paying special attention to water management and socio-economic opportunities could therefore lower the vulnerability of the "Hollands Kroon" area to these issues, making it suitable for a case study to demonstrate the new landscape planning method. For this case study, interviews were conducted with four stakeholders: representatives of the local water board ("Hoogheemraadschap Noorderkwartier"), the local government (municipality "Hollands Kroon"), the agricultural organisation representing farmers ("LTO Noord") and the state forestry service ("Staatsbosbeheer") which manages various nature reserves in the Netherlands. Due to the fact that the area is mainly agricultural, new economic opportunities will focus on diversification of the agricultural sector.

\section{Interviews}

Stakeholder interviews were divided into three main parts. In the first part, each stakeholder's perception of the current situation in the area was recorded. The second part consisted of a questionnaire aiming to learn about stakeholder opinions on individual landscape elements. In the final part, stakeholders were asked to make a visualisation of their ideal landscape plan.

The first part of the interview aimed to establish the general opinion of the stakeholder, each describing their view of the current situation. Stakeholders were asked to explain what, in their opinion, the main issues were in the study area and what issues the area would face in the future.

During the second part, stakeholders were asked to give their opinion on individual landscape elements by means of a questionnaire. The elements fall under three main categories: agricultural practices, water management techniques and other socio-economic drivers such as alternative energy sources, nature and recreational activities (Table 1). 


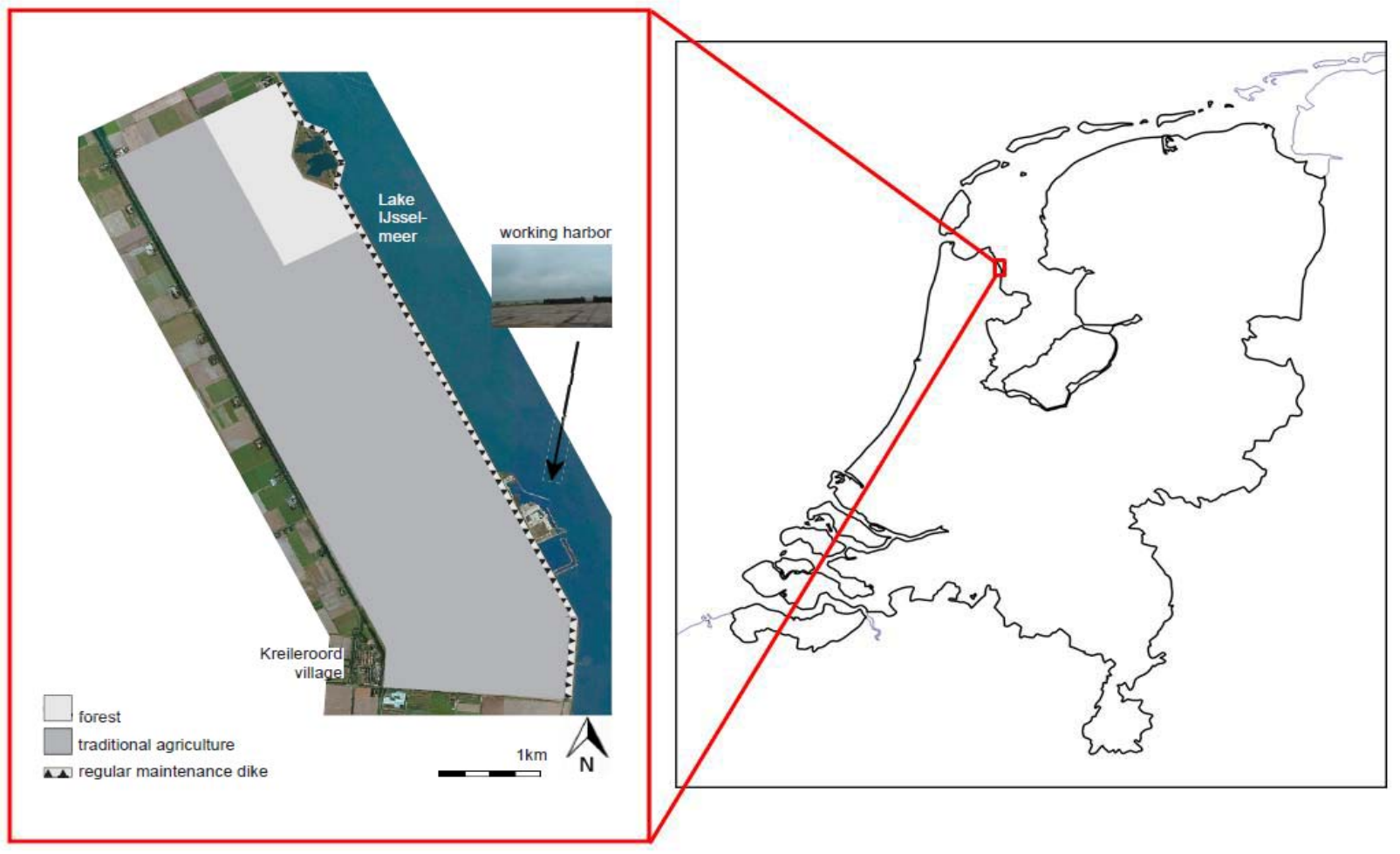

Figure 1. Location of the study area "Westvaardersplassen" in the Netherlands, and its current land use.

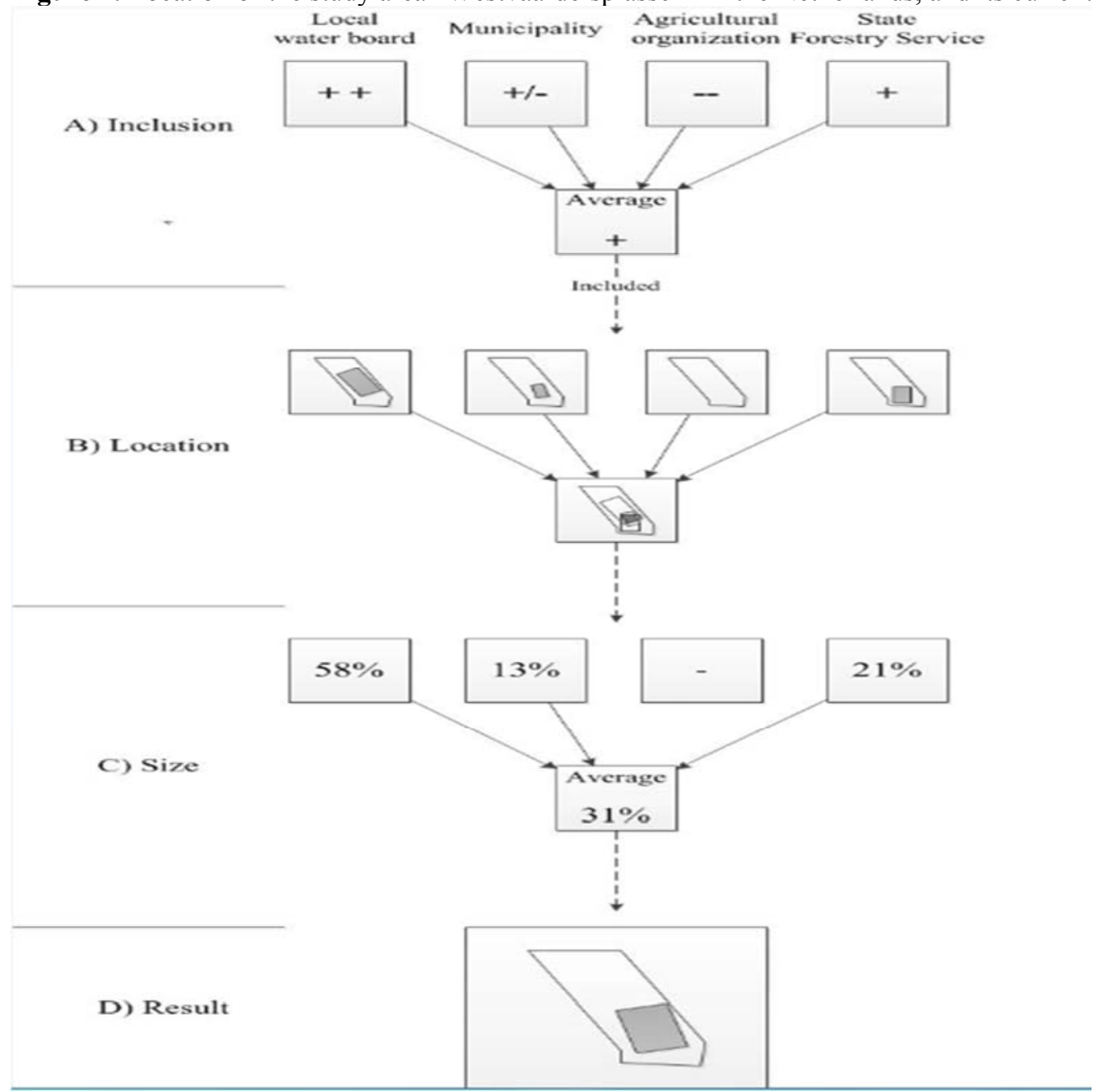

Figure 2. The translation of the interview results of a hypothetical conflicting element into the map. 
Researchers predetermined a set of elements falling under these categories but also gave stakeholders the opportunity to propose their own at the end of the questionnaire. Stakeholders were asked to rate the suitability of each landscape element to the study area on a 5-point scale, ranging from very negative (- -) to very positive $(++)$. If stakeholders had no opinion, it was perceived as neutral $(+/-)$. If stakeholders were not familiar with a landscape element or concept, they were provided with a short explanation.

During the third part of the interview, stakeholders were asked to make a visualisation of their ideal landscape plan using printed cards containing the name and description of each landscape element; these could be placed on top of a map of the area and be shifted around until positioned in a satisfactory arrangement. Some landscape elements that were not mutually exclusive, such as open water and a reservoir, could be combined in one area by stacking the cards on top of each other. A differentiation was made between spatial elements (marked with $*$ in Table 1 ), such as agricultural techniques, and point elements, such as a harbour. The spatial elements were given a location and an indication of area, whereas point elements were given a location only. In addition, some elements that were generally applicable in the whole area were noted down separately. Examples of this could be solar energy or a water management technique such as controlled drainage. Once the arrangement was final, each landscape element was drawn onto a plastic sheet overlaying the map.

\section{Integration into landscape plan}

The final landscape plan was made based solely on the results of the stakeholder questionnaires and visualisations in order to preserve objectivity. This was done in three steps (Figure 2): (1) analysis of similarities and differences between stakeholders, (2) selection of landscape elements, (3) determination of location and area size of landscape elements.

The analysis of similarities and differences between stakeholders was based on the results from the rating of landscape elements in the questionnaire and the landscape elements that were included in or excluded from the visualisations. Three groups were created: those that every stakeholder was positive or neutral about, those that every stakeholder had a negative opinion about and those over which there were conflicts. Landscape elements were considered to be conflicts if rated positively by one or more stakeholders and negatively by one or more other stakeholders. The three groups were used to make a final selection of elements to be included in the final landscape plan.

The first group (unanimously positive/neutral) of elements was included in the landscape plan, whereas the second group (unanimously negative) was excluded. For the group with conflicting ratings, inclusion in or exclusion from the final plan was based on balancing the positive and negative ratings stakeholders gave the landscape element in the questionnaire. If for instance the ratings of the stakeholders for one element were ' ++ ', '+/-', '- -' and ' + ', then the result consists of three ' + ', two '-' and one neutral. Balancing the '+' and '-' then results in one '+', or a positive result (Figure 2A). If the outcome was a neutral balance, the number of stakeholders who included the element in their visualisation was conclusive. There were two special elements that were exceptions to this method: several options were given and rated for the dike and harbour that are mutually exclusive. Therefore, for the dike and harbour, the most positive (or least negative) option was included.

As a final step, the location and size were determined for the spatial landscape elements $(*$ in Table $1)$. By creating an overlay of the locations allocated by each stakeholder to each included spatial element it was possible to see if certain locations were generally preferred for that element (Figure 2B). The location with the majority vote was chosen. If the votes were divided evenly over two locations, the area was divided over the two. The size of the element was determined by averaging the area that was allocated to that spatial element by the stakeholders who included it in their visualisation (Figure 2C). Using the locations and size determined by this method, the element was drawn onto the final map (Figure 2D).

Throughout this entire planning phase, all stakeholders were given equal weights in the determination of inclusion or exclusion of landscape elements, location and size allocation. To check the robustness of this plan, a sensitivity analysis was performed for which two alternative plans were made based on changing stakeholder weights. The main focus of the new landscape plan based on the most important issues of the area is on agricultural diversification and water management. This is reflected in the sensitivity analysis by giving the agricultural organisation and the local water board double weight. For instance, in the selection of landscape elements a ' ++ ' would count as ' + +++ '. This resulted in two alternative plans, one with an agricultural and the other with a water management focus.

\section{RESULTS}

\section{Interviews}

During the interviews, every representative was eager to formulate the viewpoint of their organisation clearly with respect to the project, especially when the current situation was discussed. The agricultural organisation and municipality both see the socio-economic situation in the village of Kreileroord as the most important issue in the study area. The municipality believes that the key solution is creating employment, both by diversifying agriculture and by stimulating recreation. The agricultural organisation, on the other hand, does not think that change is necessary. This is in line with the water board, which holds the opinion that there are no major issues in the area. The forestry service emphasises the fact that there is currently no ecological connection between nature areas in the northern and southern parts 
of the province, which is a problem for migratory animals. Also, the forestry service is the only stakeholder to consider salinisation a threat to the study area.

\section{Opinions}

The agricultural organisation, municipality and water board all expressed positive or neutral views about most of the agricultural techniques, including current conventional agriculture. The agricultural organisation stresses that they are positive about all options as long as the decisions are left to the individual farmers. Even so, they are of the opinion that agroforestry does not fit in the current landscape. The forestry service, however, would prefer to gradually replace conventional agriculture with more environmentally-friendly techniques such as organic agriculture and agroforestry. None of the stakeholders thinks that horticulture should have a place in the new landscape plan because it has already been implemented on a large scale close to the area.

Despite being of the opinion that there are no water management issues in the study area, the water board was very positive about all landscape elements in this category, with the exception of breakwater poles in the IJsselmeer. The municipality is also singularly positive about all water management elements. In contrast, the forestry service was singularly negative. The agricultural organisation did not have an opinion about the measures that are placed on the lake side of the dike, as this was not considered to affect agriculture. For the measures on the land side of the dike, controlled drainage and a fresh water reservoir were negatively rated. Though salinisation was not considered to be a problem, the agricultural organisation was positive about separating fresh and brackish ditches.

Geothermal energy was the only renewable energy type that was considered suitable for the study area, while wind energy was dismissed by all. Creating marshland and/or a bird watching area is supported by the forestry service, but the agricultural organisation and water board are both against this due to the loss of space for agriculture and the damage birds can cause to crops. The water board was wary with regard to recreational options such as the creation of a marina or an accessible dike, supporting these options only if they do not impede maintenance on the dike. All other stakeholders were in favour of making the dike more accessible, from a recreational point of view (the municipality and forestry service) or because it would relieve the traffic on the nearby road (the agricultural organisation).

\section{Visualisations}

After the questionnaire, all representatives made their own visualisation (Figure 3). There were several similarities between the implemented landscape elements. Firstly, all stakeholders would like to see organic agriculture and aquaponics in the study area, though the agricultural organisation left this option up to the farmers themselves to decide. Secondly, all representatives left the forest area that is already present in the study area forest and wished to make the dike accessible. Another common element was the inclusion of geothermal energy. Agreement was also found in elements that were not included into the visualisation by any of the stakeholders. These elements include detached breakwaters in the form of poles, diving, a high speed zone for water sports and a holiday park. The water board, the municipality and the forestry service showed no interest in beekeeping, livestock farming or horticulture. The farmer's organisation did not specifically include these elements, but again left the choice up to the farmers themselves.

One marked difference between the visualisations concerns nature. On one hand, the agricultural organisation would like to maintain the entire area that is currently under agriculture, while the forest service would like to see the addition of substantial marshland and open water. The water board and municipality were in between the previous two stakeholders in this regard, requesting limited nature areas in the form of open water. Breakwaters are another point of conflict, and even the two stakeholders that included them have different opinions on how it should look: the municipality produced a detached breakwater, while the water board created a dam with only a small opening in front of the harbour. Other examples of elements that constituted points of conflict were the fish ladder, bird watching area, houseboats, the construction of a large marina and sport fishing area.

The importance of the location of the landscape elements varied amongst the elements and different stakeholders. In some cases, the location was more or less fixed, or bound with conditions: recreational activities in general were often connected to open water areas, the harbour and/or along the main road at the edge of the study area. Restaurants, for example, were consistently found near the harbour and a cycle path was placed on the dike. In other cases, stakeholders were very flexible, indicating a possible location. For example, the municipality indicated a zone in which they would like to see aquaponics, aquaculture, open water and a marsh area, without determining where exactly it should be within this zone. Elements such as renewable energy production and water management techniques such as controlled drainage, the widening of ditches and the separation of brackish and freshwater ditches are often used as general elements.

The determination of size of the area is limited to spatial elements, such as agricultural elements, reservoirs and nature areas. It is important to note that several stakeholders said that it was difficult to indicate how much space they would like to reserve for the different elements. This was most clear for the aquaponics and saline agriculture elements. Stakeholders mentioned that they find these elements interesting, but do not know how much demand there is for the products and thus how much space would be optimal. 

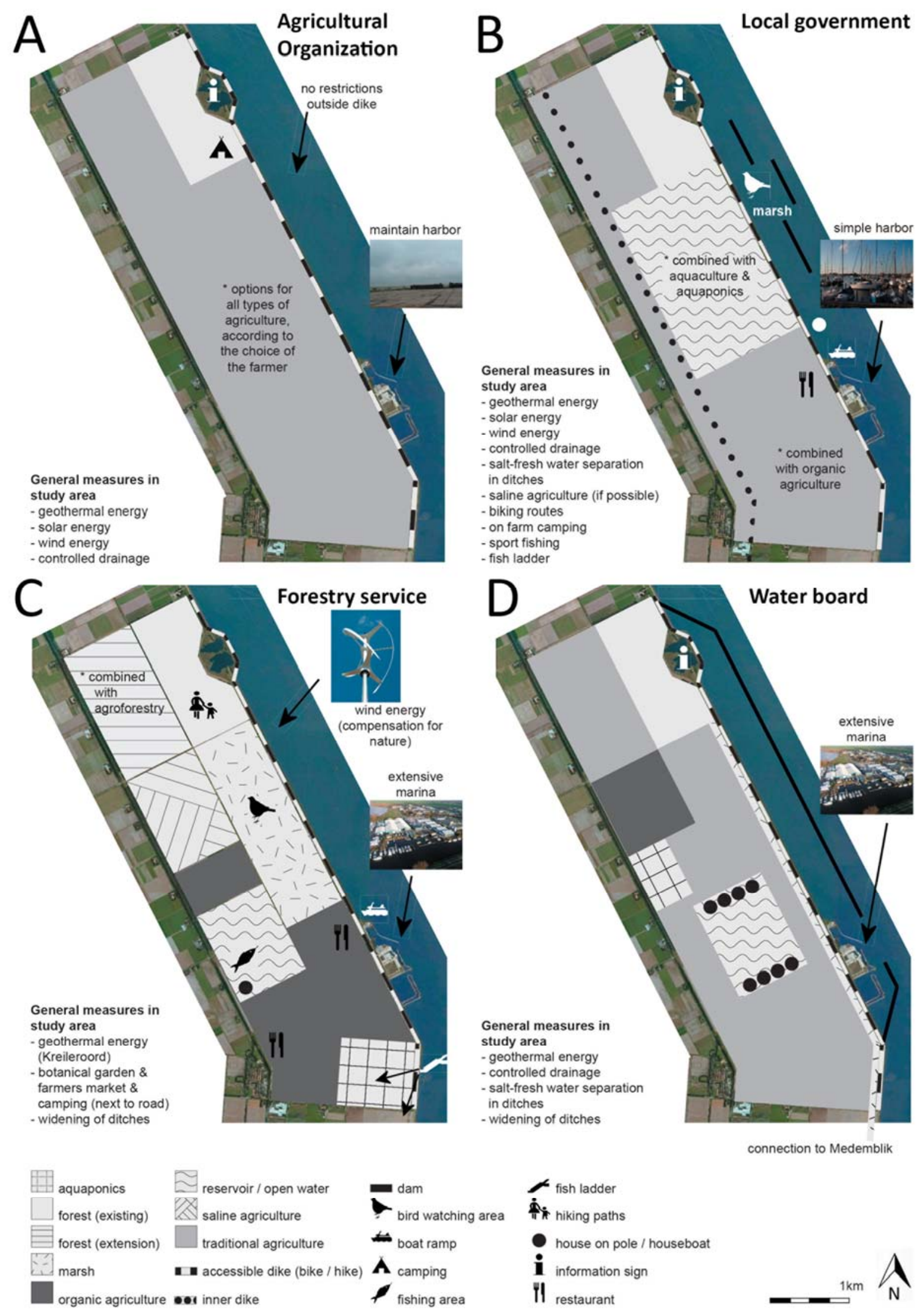

Figure 3. The visualizations of the four stakeholders: the representatives of the agricultural organization representing farmers (A), the local government (B), the state's forestry service (C) and the local water board (D). 
The main conflict concerning area size was with respect to agricultural land. The forest service reserved about half of the study area for this destination, while the agricultural organisation wished to maintain the area that is currently used for agriculture, which is almost 90 percent. The municipality and the water board were somewhere in between, allocating about 70 and 75 percent of the land to agriculture, respectively.

\section{The landscape plan}

Surprisingly, in some cases the stakeholder opinions based on the questionnaire and the visualisations were different. For example, the water board gave the accessible dike option a negative opinion, yet included this option in its visualisation. In cases where there was such inconsistency between the questionnaire and the visualisation, the results of the questionnaire were assumed to be more accurate for use in the landscape plan, as the stakeholders often gave more reasoning for their opinion during the questionnaire. The overall results of the interviews led to a landscape plan shown in Figure 4.

Similarly to the current situation, agricultural land covers most of the area in the resulting landscape plan. The total agricultural area is more than 60 percent of the area and is divided into zones of conventional agriculture, organic agriculture and aquaponics. The largest zone is reserved for conventional agriculture and aquaponics is the smallest of the three zones. The organic agriculture area is close to the village "Kreileroord" in the southeastern part of the study area.

Landscape elements in the water management category bring some changes to the area. First, controlled drainage and the separation of fresh and brackish ditches are applied as a general measure for the whole area, and interested farmers can choose to apply these on an individual basis. In addition, wave breaking dams have been placed along the dike in the IJsselmeer. However, the most evident change to the area is the addition of a fresh water reservoir to the north of the organic agriculture zone.

Beside the water management function, the reservoir gained several other purposes. First, a fish ladder connecting the IJsselmeer to the reservoir is implemented, adding a nature function to the water body. In addition, activities such as bird watching, fishing and building houses on poles add a recreational purpose. The dike is made accessible with a path for walking and cycling, stretching along the entire IJsselmeer border of the area.

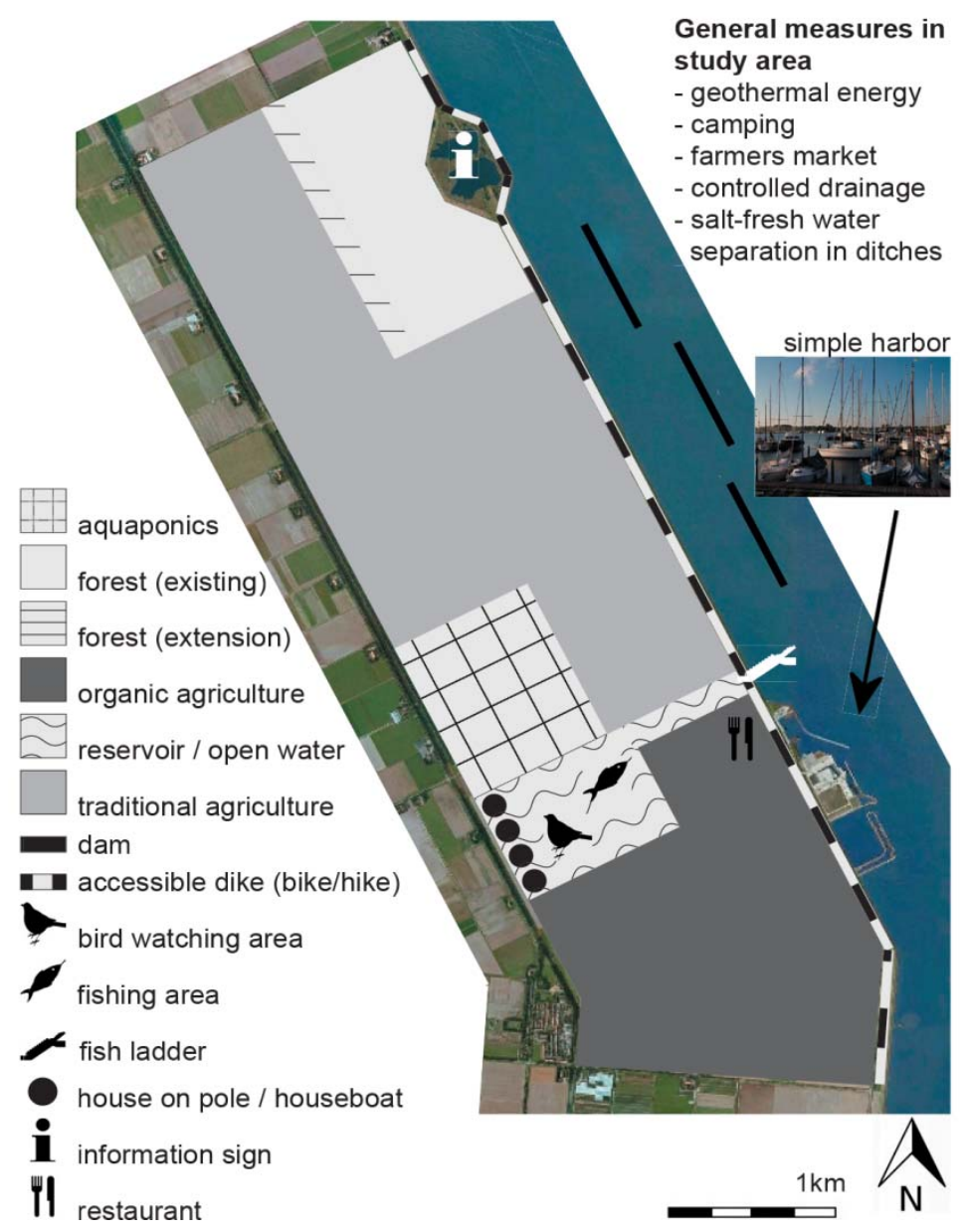

Figure 4. The landscape plan for the 1000 ha area of the "Westvaardersplassen". This plan is the result of the presented stakeholder approach method. 
A

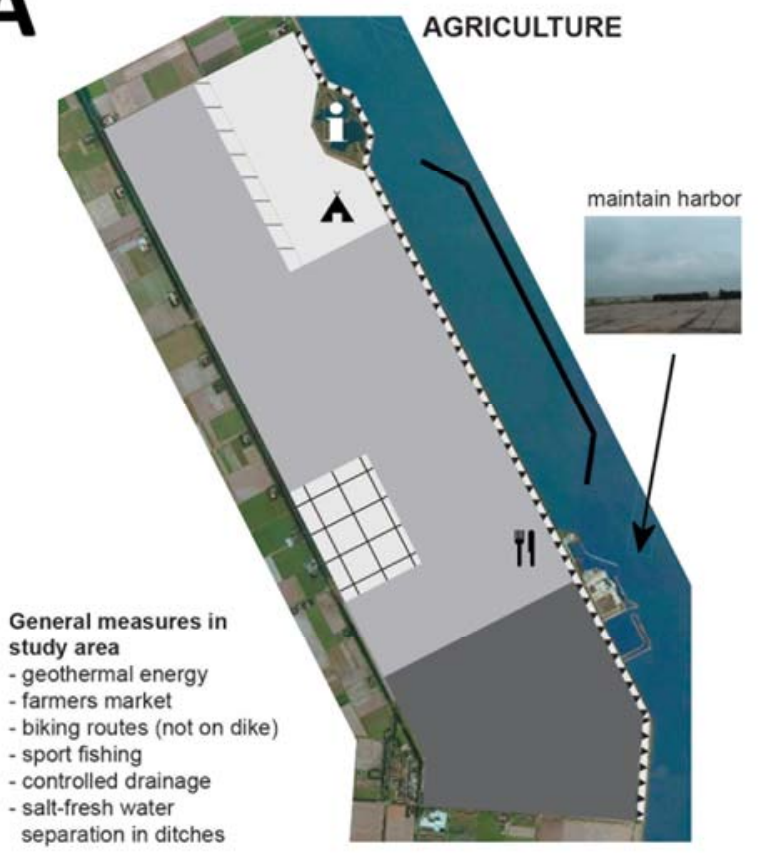

B

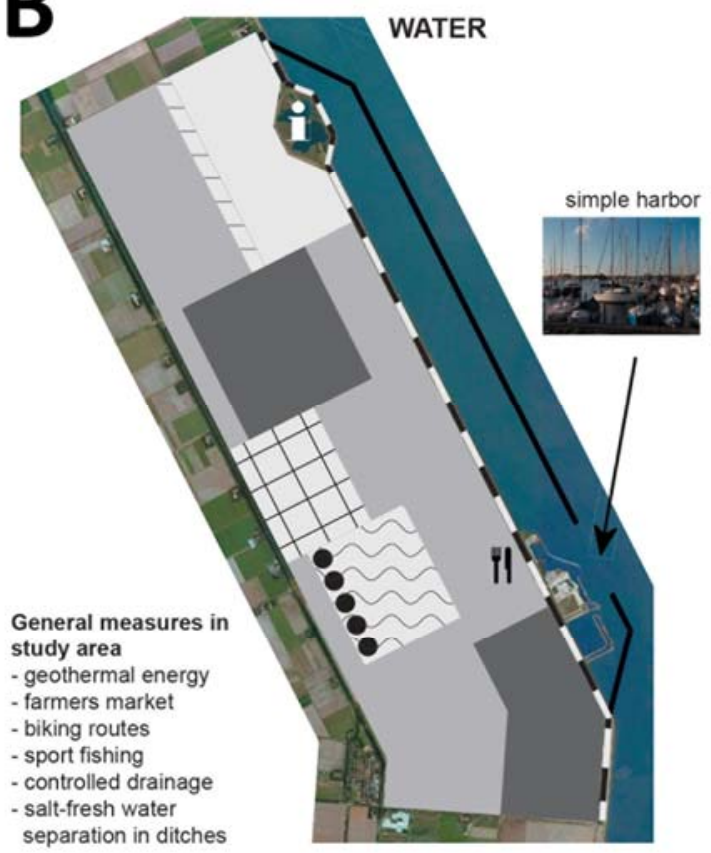

separation in ditches
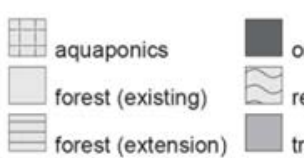

1. accessible dike (bike / hike) organic agriculture A. regular maintenance dike traditional agriculture dam

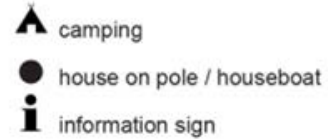

II

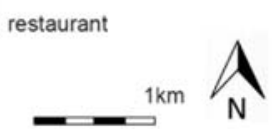

Figure 5. Results of the sensitivity analysis. In alternative 1 (A) and 2 (B) the agricultural organization and the waterboard are given double weight, respectively.

The forest area in the north was expanded by about onefifth of its original size and the 'Hole in the dike' adjacent increases in educational value through the addition of signs. In the south, the old harbour is replaced by a simple mooring harbour which is accessible for small boats. Close to the harbour and fish ladder, there is space for a restaurant. Finally, geothermal energy and a camping area are added to the area as general landscape elements.

\section{Sensitivity analysis}

The robustness of the landscape plan was tested by performing a sensitivity analysis. Specifically, the sensitivity to stakeholder weights was tested by doubling the weight given to two of the stakeholders, namely the representative of the water board and the agricultural organisation (Figure 5). These will be referred to as alternatives 1 and 2 , respectively. The results of the analysis are discussed according to each of the main topics considered in the landscape plan.

Changing the weights of the stakeholders does not influence which agricultural elements were included in the result. In each case, conventional agriculture, organic agriculture and aquaponics are the techniques included in the plan. The area allocated to each technique varies only slightly, and the location is the same except in alternative 1. In that plan, the organic agriculture is split into two locations, one of which is the same as in the other alternatives.
Most of the water management elements are shown to be very robust. For example, controlled drainage and the separation of fresh and brackish ditches are not affected by changing stakeholder weights. Though the design of the dam changes slightly with different weight distributions, it remains present. However, the water reservoir is observed to be sensitive to stakeholder weights. Though the reservoir is included in alternative 1 and is of a similar size and location to the final plan, the water reservoir is excluded from the plan in alternative 2.

Elements in the final category of other socioeconomic drivers show differences in sensitivity. Renewable energy is completely independent of stakeholder weights: geothermal energy is the only renewable source included in each of the alternatives. Nature is the topic that is most sensitive to stakeholder weights. Though the expansion of the forest area is similar in the alternative plans, the inclusion of open water is variable, similar to the reservoir, as these functions were often linked by stakeholders. In addition, the fish ladder and bird watching area are excluded from both alternative plans. Recreational elements such as a sport fishing area, an information sign near the 'Hole in the dike' and a farmers market are not affected by changing weights. Even the location of point elements such as the restaurant is similar for the alternative plans. The presence of houses on poles is linked to the presence of a water reservoir - when the reservoir is included, so 
are the houses. The type of harbour and dike included in the plans are not always the same, but neither are they extremely different. For example, leaving the harbour as it is and creating a simple mooring harbour, the two options present in the plan and alternatives, are more similar than leaving the harbour as it is and creating an extensive marina.

\section{DISCUSSION}

The importance of a stakeholder - or bottom-up approach in landscape planning has been recognised. This research is an experiment with a new method of landscape planning based on such an approach. The method is unique in that the stakeholders' opinions are first visualised and then combined into a resulting plan in an objective way. We chose to base the plan on the results of an overall questionnaire as well as a visualisation of the stakeholders' ideal landscape plan. Another option would have been to solely base the plan on the visualisation. In this case the included landscape elements would be based on the number of stakeholders to include a certain element in the plan. However, this was not chosen as stakeholders were observed to give more thought and express their reasoning on the individual elements when answering the questionnaire than when making the visualisation. In this way, it was assumed that the results of the questionnaire more closely reflected the stakeholders' opinions on the elements than the visualisation.

In order to ensure that the result is truly representative of the overall opinion, it is important to ensure that all relevant stakeholders are included in the process. The identification of these stakeholders is necessary for successful participation (Freeman et al. 1996). The question of who should be included in landscape decisions has also been proposed as a problem by Roe (2007), who emphasised that social exclusion might occur. In our case, the municipality is assumed to represent the citizens, but the question as to whether all citizens are equally represented by the municipality remains. The inclusion of more stakeholders (including citizens) is regarded as important for the application of our method.

In this method we made a decision to include only stakeholder opinions in the final landscape plan. However, it is unclear whether basing a landscape plan on stakeholder participation alone really leads to sustainable landscape plans. This depends on whether stakeholders possess the knowledge needed to tackle the main issues that are to be addressed in the new landscape plan (Roe, 2013). If stakeholders do not possess the necessary knowledge, expert knowledge must be added to the methodology in some way in order to reach the goals of the landscape plan.

It is important to note that the described case study is limited in scope. The new landscape planning method has only been applied to a specific geographical region of a limited size, meaning that the results are specific to this small area. In addition, only a small number of stakeholders were included in this first experiment. In theory, a small number of stakeholders will make the results sensitive to the opinions of the individual stakeholders when averages are taken, such as was done as part of the method. Although this was not true for this case study according to the sensitivity analysis, this effect must be taken into account in further studies.

Table 1 Overview of the landscape elements as presented to the stakeholders during the interviews.

\begin{tabular}{|c|c|c|}
\hline Category & Landscape element & Examples \\
\hline \multirow[t]{9}{*}{ Agriculture } & Traditional agriculture* & \\
\hline & Organic agriculture* & \\
\hline & Animal husbandry* & \\
\hline & Horticulture* & \\
\hline & Beekeeping & \\
\hline & Agroforestry* & \\
\hline & Saline agriculture* & \\
\hline & Aquaculture* & \\
\hline & Aquaponics* & \\
\hline \multirow[t]{4}{*}{ Water management } & Detached breakwaters & \\
\hline & Water reservoirs* & \\
\hline & Controlled drainage & \\
\hline & $\begin{array}{l}\text { Separation of fresh and } \\
\text { brackish water ditches }\end{array}$ & \\
\hline \multirow{5}{*}{$\begin{array}{l}\text { Other socio- } \\
\text { economic drivers }\end{array}$} & Renewable energy & Wind, solar, geothermal \\
\hline & Nature & Forest*, marsh*, open water, fish ladder \\
\hline & Recreation & $\begin{array}{l}\text { Agritourism, accommodation, biking and hiking routes, café/restaurant, } \\
\text { landmark 'The Hole in the Dike', water recreation }\end{array}$ \\
\hline & Options for the dike & Accessible dike for biking and hiking*, park dike* \\
\hline & Options for the harbor & Simple harbor*, marina* \\
\hline
\end{tabular}




\section{CONCLUSIONS}

Landscape degradation, which can be caused by agricultural intensification in rural areas, has created the need for sustainable development. In order to achieve this, actual community participation in spatial planning is required, as has been shown by examples in the Netherlands. This paper developed a new method of such bottom-up landscape planning based on a stakeholder approach. The landscape plan was made based on stakeholder opinions on individual landscape elements and visualisations made by each stakeholder in such a way that the influence of landscape planners is minimised. This methodology was illustrated by a case study in a rural area of the Netherlands and the effect of changing stakeholder weights was tested.

Four stakeholders were interviewed as part of the case study. Overall, the resulting landscape plan was not sensitive to stakeholder weights in the tested case, showing that the method is robust. This was especially the case for agricultural and renewable energy elements. However, certain individual elements such as the water reservoir and fish ladder were found to be sensitive to stakeholder weights.

The method was applied to a single case of limited scope, but can easily be applied to other study areas. Due to the fact that simple averaging techniques are used, the method used in this paper can easily be adapted to include a different number of stakeholders or to change the area of the landscape plan. Although the sensitivity of the method must be further tested for other cases, the presented methodology is a promising new method for robust and objective landscape planning.

Acknowledgments: The authors would like to thank Suzanne Koenen, Annemieke de Kort and Nateepat Pitinidhipat for their participation in developing and applying the stakeholder analysis. Also, Wouter de Zeeuw and Antoon de Vries from FOM Consultants, whose project "Kreil Westvaardersplassen" provided us with inspiration and the means to perform a case study. The involvement of Roel Doef from the national water board "Rijkswaterstaat" is also highly appreciated. Additionally, the authors would like to thank the interviewed stakeholders for their cooperation: Karel Bruin-Baerts from the local water board ("Hoogheemraadschap Noorderkwartier"), Harrie Wenink from the local government (municipality "Hollands Kroon"), Hans Ghijssels, Ard Mooij and Leendert Koolen from the agricultural organisation representing farmers ("LTO Noord") and André Smit from the state's forestry service ("Staatsbosbeheer"). Finally, Lijbert Brussaard and Peter Tamas from Wageningen University are thanked for their involvement and advice.

\section{REFERENCES}

ALSTON, M. (2004) 'You don't want to be a check-out chick all your life': The out-migration of young people from Australia's small rural towns. Australian Journal of Social Issues, 39(3), pp. 299-313.
BAAS H.- GROENEWOUDT B.- RAAP E. (2011) The Dutch approach - Public Participation and the Role of NGOs and Local Authorities in the Protection, Management and Development of Cultural Landscapes in the Netherlands, in: Jones M. \& Stenseke M. (Eds) The European Landscape Convention - Challenges of Participation (Dordrecht, The Netherlands: Springer Landscape Series).

BODEMRICHTLIJN (2012) Aardkundige waarden in droogmakerijen en nieuwe polders. [online] Available at: http://www.bodemrichtlijn.nl/Bibliotheek/bodembescher ming/aardkundige-waarden/aardkundige-waarden-in-

droogmakerijen-en-nieuwe-polders [Accessed

December 2012].

CHURCH, J.A. - WHITE, N.J. (2006) A 20th century acceleration in global sea-level rise. Geophysical Research Letters, 33, L01602.

FREEMAN C.- LITTLEWOOD S.- WHITNEY D. (1996) Local government and emerging models of participation in the Local Agenda 21 process, Journal of Environmental Planning and Management, 39(1), pp. 6578.

GARROD, G. - WILLIS, K.G. (1999) Economic Valuation of the Environment; Methods and Case Studies, (Cheltenham, UK; Northampton, MA, USA: Edward Elgar Publishing).

GRGIĆ, I.- ŽIMBREK, T.- TRATNIK, M.MARKOVINA, J.- JURAČAK, J.(2010) Quality of life in rural areas of Croatia: To stay or to leave? African Journal of Agricultural research, 5(8), pp. 653-660.

HAARTSEN, T.- VAN WISSEN, L. (2012) Causes and consequences of regional population decline for primary schools. Tijdschrift voor Economische en Sociale Geografie, 103(4), pp. 487-496.

HEIDE, C.M. van der - BLAEIJ, A.T. de - HEIJMAN, W.J.M. (2013) Payments for ecosystem services in Natura 2000 habitats: the heathlands case, in: Diemont W.H., Heijman W.J.M., Siepel H. and Webb N.R., Economy and Ecology of heathlands, pp. 301-321. (Zeist, The Netherlands: KNNV Publishing).

HEIJMAN W. - GOOSSEN M. (2009) Consumer Preference in Landscape Design. In: CEEP, Proceedings First International Conference on Landscape Economics, pp. 9-18, Vienna: BOKU.

Intergovernmental Panel on Climate Change (2007) IPCC Fourth Assessment Report: Climate Change. Intergovernmental Panel on Climate Change.

LANCASTER K.J. (1966) Change and innovation in the technology of consumption. American Economic Review: Papers and Proceedings, 56, pp. 14-23.

LOUVIERE, J.J.-, HENSHER, D.A.- SWAIT, J.D. (2000) Stated Choice Methods: Analysis and Application, (Cambridge: Cambridge University Press).

LUZ, F. (2000) Participatory landscape ecology - A basis for acceptance and implementation. Landscape and Urban Planning, 50(1-3), pp. 157-166.

MATHOT, K.- MAGWENZI, K.- POL, B. VAN DENRIET, J.- SINGH, M.- ZAVALLONI, M. (2011) Towards a dynamic Kreil. Wageningen University, unpublished. 
OPDAM, P.- STEINGRÖVER, E.- ROOIJ, S. VAN. (2006) Ecological Networks: A spatial concept for multiactor planning of sustainable landscapes. Landscape and Urban Planning, 75, pp. 322-332. http://dx.doi.org/10.1016/i.landurbplan.2005.02.015

OUDE ESSINK, G.H.P., BAAREN, E.S., DE LOUW, P.G.B. (2010) Effects of climate change on coastal groundwater systems: A modeling study in the Netherlands. Water Resources Research, 46, W00F04, http://dx.doi.org/10.1029/2009WR008719

OUŘEDNÍČEK, M., ŠPAČKOVÁ, P., FEŘTROVÁ, M.(2011) Changes in social milieu and quality of life in depopulating areas of the Czech Republic [Změny sociálního prostřfedí a kvality života $\mathrm{v}$ depopulačních regionech České republiky]. Sociologicky Časopis, 47(4), pp. 777-803, Abstract only.

PRICE C. (2008) Landscape Economics at Dawn: An Eye-witness Account. Landscape Research, Vol. 33(3), pp. 263-280.

http://dx.doi.org/10.1080/01426390802045897

REES, P., VAN IMHOFF, E., DURHAM, H., KUPISZEWSKI, M., SMITH, D. (1998) Internal migration and regional population dynamics in Europe: Netherlands case study. Working Paper. School of Geography, University of Leeds.

ROE, M. (2007) 'The Social Dimensions of Landscape Sustainability' in: Landscape and Sustainability, eds. Benson, J. F. and Roe M. H., Routledge, Oxford, pp. 5883.
ROE, M. (2013) 'Landscape and Participation' in: The Routledge Companion to Landscape Studies, eds. P. Howard, I. Thompson, E. Waterton, Routledge, New York, pp. 335-352.

SELMAN P. (1996) 'Chapter 1: The nature of local sustainability' in Local sustainability: Managing and Planning Ecologically Sound Places, (London: Chapman).

SELMAN P. (2004) Community participation in the planning and management of cultural landscapes, Journal of Environmental Planning and Management, 47(3), pp. 365-392. http://dx.doi.org/10.1080/0964056042000216519

SHERIF, M.M., SINGH, V.P. (1999) Effect of climate change on sea water intrusion in coastal aquifers. Hydrological Processes, 13, pp. 1277-1287. http://dx.doi.org/10.1002/(SICI)1099-

1085(19990615)13:8\%3C1277::AID-

HYP765\%3E3.3.CO;2-N

TRESS, B.- TRESS, G. (2003) Scenario visualization for participatory landscape planning - a study from Denmark. Landscape and Urban Planning, 64(3), pp. 161-178.

WARRICK, R.A. - OERLEMANS, J. (1990) Climate Change - The IPCC Scientific Assessment. Cambridge University Press, pp. 257-281. 